protected by guards, taps for gas secured under lock and key, and all windows and gas jets be placed out of reach.

Patients should bs watched at meals to see that they eat enough, and do not take food in a dangerous manner.

Some curious weapons were exhibited, made by suicidal patients from pieces of crinoline steel, firewood and string forming a knife, and from stones tied up in a stocking forming a hammer, and other curious inventions.

The paper concluded by a tribute of praise to the attendants, by whose devotion suicide in asylums is reduced to a minimum.

\title{
ILLENAU'S GOLDEN JUBILEE.
}

Since we received the "Festschrift," issued at the time of the Jubilee, which we have noticed in this Journal (p. 109), we have received from the Director, Dr. Schüle, an account of the proceedings which took place at Illenau on the 27 th September, 1892.

Our space allows us only to note that the occasion was a very brilliant one. The Grand Duke and Grand Duchess of Baden honoured it by their presence. The ceremony was partly religious, partly secular. A sermon was delivered by the Chaplain. The Duke replied to a loyal speech in which he was addressed. Dr. Schüle, of course, spoke. Among other things a hymn, specially written for the Ceremony, was sung at the Service, and a special poem eulogizing the work performed at Illenau was recited during the proceedings. Altogether the enthusiasm and the tributes paid to those who had been the making of the asylum were of the warmest character, and the success was, we are glad to say, as great as it deserved to be. Congratulations in regard to the past were combined with the expression of the hope that in the future still greater heights would be reached in the treatment of the insane. We add our "Amen!"

\section{Obituary.}

THOMAS AITKEN, M.D.EDIN.

We regret to have to record the death of Dr. Aitken, of the Inverness District Asylum, one of the senior members of the Medico-Psychological Association.

Dr. Aitken was born in Dumfries, and was rocked in his cradle by the widow of the poet Burns. After attending school in Birmingham he served as assistant medical officer under the late Dr. W. A. F. Browne in the Crichton Royal Institution, and thereafter completed his medical education in Edinburgh. He graduated in 1856 and then became assistant medical officer in Durham County Asylum with Dr. R. Smith, before being appointed Superintendent of the Inverness Asylum in 1859. That institution was completed in 1863, and was designed to accommodate 300 patients. Since then it has been repeatedly enlarged, and now contains over 500. Further accommodation being urgently required, Dr. Aitken was, until the time of his sudden illness, occupied in designing a separate hospital block for the reception of acute cases. Although it was well known that for some years his health was far from being robust, and 
that at times he carried on his life-work under circumstances of painful difficulty that would have daunted a less resolute man, his health had improved so much of ;late that Dr. Aitken's death at Baden was a shock to his many friends who had parted so recently from him in high spirits and the prospective enjoyment of a holiday in Germany.

His loss will be widely felt, not only by those with whom he was more intimately professionally connected, but also by the public in the north of Scotland. Dr. Aitken did not confine his energies to the administration of asylum affairs, but he was also a good citizen and a man of no ordinary accomplishments, both literary and scientific. He was deeply interested in archæology and geology, and specially wrote on the Hill Forts so common in the north of Scotland. All his life long he was an eager student. His collection of books on the French Revolution was very complete; and his study of Heine, and the poetry of Keats and Wordsworth was both comprehensive and erudite. Dr. Aitken had a full knowledge of French and German, and has left many translations from works in these languages, not only from those dealing with psychiatry, but also from such poets as Heine.

Dr. Aitken did not publish any work of note in psychological medicine, although ke was ever careful to keep abreast with the foremost knowledge of the time. His conscientious reports have been noticed from time to time in this Journal, and although his views did not always command assent, they were respected as the outspoken accents of sincere conviction.

A. R. U.

\section{PROSPER DESPINE.}

Dr. Despine, of Marseilles, died there January 16th, 1892, at the age of eighty.

He was an honorary member of the Medico-Psychological Assooiation.

A native of Savoy, he commenced his medical studies in the Marseilles School of Medicine; he pursued and finished them in Paris, where he obtained his degree of M.D. in 1837.

Despine was interne at Bicêtre under Ferrus and Leuret. It was under the direction of these enlightened alienists and also by associating with fellowstadents, who were themselves afterwards distinguished masters of mental science, that Despine acquired a keen taste for the study of the problems of psychology and medical philosophy. He was the author of several works of profonnd erudition, in which he proved himself to be a mental philosopher, and, in some respects, an able exponent of the Scotch metaphysical school. Such are his " Psychologie naturelle on Etude sur les facultés intellectuelles ou morales dans leur état normal, et dans leurs manifestations anormales chez les aliénés et chez les criminelles" (1868): "De la folie au point de vue philosophique ou plus spécialment psychologique chez le malade et chez l'homme ez santé" (ouvrage conronné par l'Institut ez 1874), "Etude scientifique du somnambulisme" (ouvrage récompensé par la Société medico-psychologique de Paris, 1877). He also published "La Contagion morale" (1870), "L'imitation on les principes qui la déterminent" (1871), "Le démon alcool" (1871), "De l'état psychique des criminels," "Un cas d'hystérie aigüe chez l'homme," etc. His last work was an interesting study on Moliere, in which he studied the illustrious comedian as moralist and as philosopher. Its title was "La Science du cœur hnmain" (1884).

Dr. Despine was an honorary member of the Société Medico-Psychologique of Paris, of the Académie des Sciences, Belles Lettres et Arts of Savoy, and of the American Society of Prisons. His great age did not allow of his taking 